\title{
Risk Factors of Colorectal Cancer; A Case-Control Study
}

\author{
Sheref M. El-taher*, Awwad Alenezy ${ }^{* *}$, Basem M. M. Salama ${ }^{* * *}$ and Taha M. M. \\ Hassan $^{* * * *}$ \\ * Community Medicine and Public Health Department, Faculty of Medicine, Benha \\ University (Egypt). \\ ** Family Medicine Consultant, Family and Community Medicine Department, Faculty \\ of Medicine, Northern Border University (KSA). \\ *** Community Medicine and Public Health Department, Damietta Faculty of Medicine, \\ Al-Azhar University (Egypt). \\ ***** Pathology Department, Faculty of Medicine, Bani-Seuif University (Egypt). \\ Received: April 2015, accepted: December 2015
}

\begin{abstract}
Background: Colorectal cancer is one of the commonest malignant tumors worldwide. Life style factors may contribute to the etiology of colorectal cancer as they are modifiable. A better understanding of the associations between lifestyle related factors and colorectal cancer risk may be of importance in order to develop novel strategies for prevention of the disease. This study aimed at identifying some risk factors of developing colorectal cancer and assessing the validity of carcinoembryonic antigen as a screening test for colorectal cancer. Subject and methods: Case-control study, hospital-based study, 25 cases and 100 controls investigated by colonoscopy and confirmed histologically between October 2011 and March 2013. Results: All cases were adenocarcinoma among them 18 (72\%) cases were well to moderately differentiated carcinoma. The majority of the cases were diagnosed as pT1 (80\%); whereas the minority were pT3 $(12 \%)$. There was a significant association between history of diabetes mellitus, high BMI (>30), smoking and dietary habits ( $\mathrm{p}<$ 0.05 ), while age, sex of participant and family history of colorectal cancer, physical activity and NSAID intake were not significantly associated with colorectal cancer ( $p$ $>0.05$ ). The best combined sensitivity and specificity of CEA was at cutoff 5.5 $\mathrm{mcg} / \mathrm{dl}$. Conclusion: Exposure to personal and environmental risk factors play an important role in the development of colorectal cancer.
\end{abstract}

Key Words: colorectal cancer, physical activity, smoking and dietary habits

*corresponding author, Email sherefmoh@gmail.com(Sheref M. El-taher)

\section{Introduction}

Colorectal cancer (CRC) is one of the commonest malignant tumors worldwide and represents the second cause of cancer-related death in certain regions. Epithelial tumors of the colon and rectum are frequent pathologic entities and deserve to be histologically reported with accuracy and completeness ${ }^{(1)}$.

The rates of CRC in Egypt were reported from the Gharbiah cancer registry where the age-standardized incidence rates for CRC were 6.5/10 for males and $4.2 / 10^{5}$ for females ${ }^{(2)}$.

There are many known factors that increase or decrease the risk of CRC; some of these factors are modifiable and others are not. Non-modifiable risk factors include a personal or family history of CRC or adenomatous polyps, and a personal history of chronic inflammatory bowel disease ${ }^{(3)}$. 
Modifiable risk factors that have been associated with an increased risk of CRC include physical inactivity, obesity, and high consumption of red or processed meat, smoking, and moderate-to-heavy alcohol consumption. About one-quarter of CRC cases could be avoided by following a healthy lifestyle, i.e., maintaining a healthy weight, being physically active at least 30 minutes per day, eating a healthy diet, not smoking, and not drinking excessive amounts of alcohol $^{(4)}$.

The histologic type of CRC should be evaluated according to the WHO classification (5). Additionally, histologic grading should be in accordance with the system used in advanced CRC and distinguish well / moderately (low grade) from poorly differentiated (high grade) tumors. An anaplastic component (even in the form of small, single or scattered foci) should be identified, as its occurrence strongly correlates with the risk of lymph node metastases. This grading schedule is mainly based on the 2tiered grading system of the WHO classification $^{(6)}$.

Previous hospital-based studies in Egypt, included analysis of the 1364 cases of CRC collected at the Gharbiah population-based cancer registry from 1999-2007 revealed the following important findings: patients over age 40 years in Egypt have significantly lower incidence of CRC than subjects in the same age group in Surveillance Epidemiology and End Results Program (SEER) of the United States. Second, high proportion of tumors are located in the rectum, third, a vast majority of tumors (over 97\%) did not have polyps, fourth, living in an urban area was associated with higher rates of $\mathrm{CRC}$, with variability in rates across the region ${ }^{(2)}$.

Carcinoembryonic antigen (CEA) is a glycoprotein, which is present in normal mucosal cells but increased amounts are associated with CRC. Levels exceeding $10 \mu \mathrm{g} / \mathrm{L}$ are rarely due to benign disease ${ }^{(7)}$.

$\mathrm{CRC}$ and its risk factors were more studied in developed countries than that in developing countries. Egypt is a developing Middle-Eastern country. So it was the idea to do this work.

\section{Aim of the study}

The goal of this study is to prevent the occurrence of CRC through maintaining a healthful life style and avoidance of risk factors.

The aim of this study was to identify different risk factors associated with colorectal cancer (CRC) and to assess the validity of carcino-embryonic antigen (CEA) as screening test for Colorectal cancer.

\section{Subject and methods:}

Case-control, hospital-based study was undertaken between October 2011 and March 2013 in Arar central Hospital, Northern Border Region, KSA. 200 suspected CRC were examined clinically, investigated by quantitative measurement of CEA and then prepared for endoscopic examination and biopsies were taken for histological evaluation. Only 25 cases were confirmed histologically as CRC, (these cases comprised our study group). For each case, four controls were randomly selected by simple random computer based sampling method from the same population who gave negative histological result regarding $\mathrm{CRC}$, during the same period and gave their consent to participate in the research; persons diagnosed to have any other malignant tumor and anyone who refuse to participate in this study was excluded. An approval from the Research Ethics Committee in Arar Faculty of Medicine was obtained to conduct this work. A written informed consent was obtained before 
participation. An official permission to apply this study was obtained from the administration of the hospital.

Specimen were collected, fixed in $10 \%$ formaldehyde and sent for histopathological evaluation. The sent specimens were stained by hematoxylin and eosin $(\mathrm{H} \& \mathrm{E})$, then examined by two consultant pathologists. The CRC cases were evaluated for the histological types, degree of differentiation, lymph node involvement, and TNM staging classification of CRC was applied ${ }^{(8)}$. Additionally other associated lesions as inflammation or polyps were looked for.

All participants were interviewed and their files were properly examined for collection of information related to the following variables: age, sex, family history, weight and height to calculate BMI, physical activity (about 1 time/week, less than 3 times/week or more than 3 times/ week), dietary pattern (Red meat consumption: weekly consumption was considered 3 or more servings of red meat a week or vegetable consumption: daily consumption was considered 3 or more servings of vegetables a day), history of DM, smoking and NSAID usage for chronic diseases and all these data were collected in data collection sheet.

\section{Statistical analysis}

Statistical analysis was undertaken using SPSS computer software (SPSS Version 16 for Microsoft Windows), Categorical data were presented as number and percentages, Inter-group comparison of categorical data was performed by using chi square test $\left(\mathrm{X}^{2}\right.$ value) and Fisher's exact test. Odds ratio and 95\% CI were calculated and ROC curve was used to measure sensitivity and specificity of CEA at different cut-off points. Results were considered to be statistically significant at $\mathrm{p}<0.05$.

\section{$\underline{\text { Results }}$}

Table (1): In concern to the age of CRC patients it ranged from the $4^{\text {th }}$ to $8^{\text {th }}$ decade yet the majority of cases were above 55 years old (88\%) with $64 \%$ of cases males. At the time of presentation and during radiographic investigation, $28 \%$ of the cases had focal liver lesions, whereas the rest of them were free from liver masses radiologically. Additionally, $40 \%$ of the received cases were complaining of intestinal obstruction. Lower endoscopy revealed colonic polypoid masses near the anal canal by a distance ranging from $10-30 \mathrm{~cm}$ in $80 \%$ of cases. In the same theme carcinoembryonic antigen (CEA) was performed and a level of less than 5 $\mathrm{mcg} / \mathrm{dl}$ was observed in $20 \%$ of CRC cases, whereas a level of $\geq 5$ was observed in $80 \%$.

\section{Table (2): regarding Histopathological findings}

Eighty percent $(80 \%)$ of the specimens were colonic biopsies, whereas the remaining were colonic resection. All the cases were adenocarcinoma. Well to moderately differentiated CRC encompassed the large number of the cases (fig1, 2a \& b), whereas a minority were poorly differentiated ( $72 \%$ and $28 \%$ respectively). In the same way associated stromal lymphocytic infiltrate was found in 4 out of the 25 cases (16\%) (Fig 3). Regarding the resection colectomy specimens; malignant deposits in the pericolic lymph nodes were detected in 3 out of the 5 cases $(60 \%)$ and the majority of them were stage III (3/5), whereas the minority were either stage I or II $(20 \%)$.

Table (3) showed that:

There was no significant difference between CRC group and control group regarding age. Age > 55 years, 
compared with age 45-55, was associated with greater risk of CRC $(\mathrm{OR}=2.6,95 \% \mathrm{CI}=0.8$ to 8.1$)$, male to female ratio in CRC was $64 \%: 36 \%$ while in control 63\%:37\%.regarding family history of $\mathrm{CRC}$, there was $1(4 \%)$ of cases with positive family history while $24(96 \%)$ had no family history, while in control group positive family history was $1(1 \%)$ and no family history was 99(99\%).

\section{Table (4) revealed that:}

There was significant difference between CRC group and control group regarding BMI. BMI of $30 \mathrm{~kg} / \mathrm{m}^{2}$ or more, compared with a BMI of less than $30 \mathrm{~kg} / \mathrm{m}^{2}$, was associated with greater risk of $\mathrm{CRC}(\mathrm{OR}=3.6,95 \% \mathrm{CI}$ $=1.47$ to 9.02 ).

There was an inverse (statistically nonsignificant, $\quad(p=0.57)$ association between physical activity and risk of colon cancer. Participant who had low physical activity, compared to those who had high physical activity, was associated with a greater risk of CRC $(\mathrm{OR}=1.9,95 \% \mathrm{CI}=0.4$ to 9.2$)$.

Regarding dietary habits, mostly meat eaters participant, compared with mostly vegetarian participant, was associated with greater risk of CRC $(\mathrm{OR}=3.9,95 \% \mathrm{CI}=1.1$ to 14.1$)$.

Regarding diabetes, most of the participants in the case group $(76 \%)$ were diabetic compared to the control group $(51 \%)$, the difference was statistically significant, $(\mathrm{p}<0.01)$. And also diabetic patients were 3.04 at a higher risk for CRC.

As regards smoking, current smoker, compared with non-smoker was associated with higher risk of CRC (OR $=4.7,95 \% \mathrm{CI}=1.4$ to 15.5$)$. Also exsmoker, compared with non-smoker, was associated with greater risk of $\mathrm{CRC}(\mathrm{OR}=4.6,95 \% \mathrm{CI}=1.2$ to 17.5$)$.
The difference was statistically significant.

As regards use of NSAID for chronic diseases, history of NSAID intake was higher but with no statistically significant difference in control group $51(51 \%)$ compared to CRC cases 11 (44\%). It also revealed that NSAID users are less likely to develop CRC $(\mathrm{OR}=0.8,95 \% \mathrm{CI}=0.3$ to 1.8$)$.

As regards intestinal polyps, higher CRC risk was observed in cases with a history of (suffered from) intestinal polyps compared to cases without (OR $=5.9,95 \% \mathrm{CI}=1.74$ to 22.0 ).

Regarding Irritable bowel disorders (IBD), higher CRC risk was observed in cases suffering from IBD compared to cases without (did not suffered from) $\mathrm{IBD}(\mathrm{OR}=2.02,95 \% \mathrm{CI}=1.07$ to 5.9$)$.

\section{Table (5) revealed that:}

The best combined sensitivity and specificity was at cutoff $5.5 \mathrm{mcg} / \mathrm{dl}$ ( $80 \%$ and $76 \%$ respectively)

\section{Discussion}

Life style factors may contribute to the etiology of several cancer forms including $\mathrm{CRC}$ and, since they are modifiable, a better understanding of the associations between lifestyle related factors and CRC risk may be of importance in order to develop novel strategies for prevention of the disease (9).

There is great interest now in strengthening prevention and even improve the prognosis of patients with CRC, led to identify a number of risk factors and recognition of the genetic component of CRC based on mutations inherited in germ cells or appeared in somatic cells after an environmental impact ${ }^{(10)}$. 
In our study the age of CRC cases was significantly higher than that of control group; the results of this study coincide with the result of other studies, which revealed that CRC predominant in patients over 50 years (11-13). Aging does not seem to be the root cause of the disease; generally accepted that as it prolongs life, increases exposure period proportionally many carcinogens which increases the risk ${ }^{(14)}$.

This study revealed that CRC wasn't significantly associated with sex of the participants, and there was slightly higher risk of association in men than women, which is in agreement with Murphy et al., ${ }^{(15)}$ who stated that overall, CRC incidence rate are about $35 \%$ to $40 \%$ higher in men than in women. And also coincides with Gao et al., ${ }^{(16)}$ who stated that CRC rate was higher in males than females. This may be explained by the protective effect of both estrogen and progesterone, this explanation is supported by several epidemiological studies have shown that elevated levels of estrogen and progesterone is associated with lower risk of developing CRC ${ }^{(17,18)}$, other studies found no reduced risk of CRC in women with higher levels of estradiol and estrone, suggesting that progesterone is the key factor for reduction of CRC risk in women ${ }^{(19-21)}$.

Our study stated that no statistical significance difference between CRC cases and control group as regards family history, $4 \%$ of CRC cases had positive family history. Lynch and Chapelle ${ }^{(22)}$ found that about $20 \%$ of all CRC patients have a close relative who was diagnosed with the disease. Also this study revealed that those with positive family history were 4.1 more risky to develop CRC, many studies investigated family history in CRC stated that people with a first-degree relative who has had CRC have 2 to 3 times the risk of developing the disease compared to individuals with no family history; if the relative was diagnosed at a young age or if there is more than one affected relative, risk increases to 3 to 6 times that of the general population ${ }^{23}$, 24).

Our finding revealed that there was significant increase in BMI in those with CRC than the control group; this is in consistent with Huxley et al., (25) who stated that being overweight or obese is associated with a higher risk of CRC, with stronger associations more consistently observed in men than in women. and also numerous epidemiological studies and metaanalyses which examined the relationship between body weight and body mass index (BMI) and CRC, and most studies had shown a positive relationship between a high BMI and risk of colon cancer in men, whereas weak or no associations were reported in women (26-28) but Positive associations between BMI and risk for colon and rectal cancer in men and risk for colon cancer in postmenopausal women have been found in previous Korean health insurance studies ${ }^{(29,30)}$.

A number of mechanisms have been proposed to account for the association of obesity with increased colon cancer risk. Obesity acts as a risk factor of colorectal carcinogenesis by several mechanisms. Isulin, insulin-like growth factor, leptin, adiponectin, microbiome, and cytokines of chronic inflammation. have been understood as its potential mechanisms ${ }^{(31)}$.

Physical activity has been found to reduce the risk of CRC in our study. This in agreement with other studies ${ }^{32-}$ 35), that found the protective effect of physical activity against large bowel cancer 
High levels of physical activity decrease the risk of colon cancer among men and women by possibly as much as $50 \%$ (36). Most studies find that, the more physical activity in which people engage, the lower their risk of colon cancer. In men and women, both recreational and occupational physical activity decrease risk ${ }^{(37)}$. Sedentary people who become active later in life may also reduce their risk $^{(38)}$.

Several mechanisms have been proposed for the role of physical activity in reducing colon cancer risk including decreased inflammation, reduced intestinal transit time, decreased insulin-like growth factor levels, reduced hyperinsulinemia and modulated immune function with physical activity ${ }^{(33)}$.

Our study showed that participants who depended mainly on meat at their meals had 3.9 (with 1.1-14.1 95\% CI) more risk to develop CRC, our results correspond to Several studies that have found that high consumption of red and/or processed meat increases the risk of both colon and rectal cancer ${ }^{(25,39)}$. Further analyses indicate that the association with red meat may be related to the cooking process because a higher risk of CRC is observed particularly among those individuals who consume meat that has been cooked at a high temperature for a long period of time ${ }^{(36)}$.

Geographic differences in CRC rates and changing risks among immigrant populations over time suggest that diet and lifestyle strongly influence CRC risk; however, research on the role of specific dietary elements on CRC risk is still accumulating. Studies suggest that following the Society's dietary recommendations (consume a healthy diet with an emphasis on plant sources; namely: limit consumption of red and processed meats, eat a variety of vegetables and fruits, and choose whole grains in preference to processed grains) and consuming the recommended levels of calcium will help reduce the risk of developing $\mathrm{CRC}^{(25,40)}$.

In contrast to our findings, large prospective studies do not indicate a major relationship between $\mathrm{CRC}$ and vegetable, fruit, or fiber consumption $(36,41)$.

Factors especially obesity, diet, and physical activity, may affect colorectal pathogenesis through 5'-adenosine monophosphate-activated protein kinase (AMPK) signalling pathways. AMPK is a cellular energy and nutrient sensor that suppresses cell proliferation including activation of $\mathrm{p} 53$, a tumour suppressor. AMPK is suppressed by obesity, physical inactivity, and poor $\operatorname{diet}(34,35,42,43)$.

Regarding diabetes, being diabetic is associated with a higher risk of colorectal cancer. Our finding are also supported by other study, that found an increased risk of CRC in patients with Type 2 diabetes (44), as hyperinsulinemia is also related to increased levels of insulin-like growth factor 1 , which is known to have cancer promoting effects ${ }^{(45)}$.

Metabolic risk factors may contribute to carcinogenesis through affecting insulin resistance, aromatase activity, adipokine production, angiogenesis, glucose utilization, oxidative stress, and DNA damage ${ }^{(46)}$. Diabetes mellitus has been associated with a $30 \%$ elevated risk for $\mathrm{CRC}^{(47)}$.

Our study revealed that smokers were the more risky to develop CRC, then ex-smokers but non-smoker which had decreased risk of developing it, Two 
meta-analyses which included only prospective cohort studies found that current cigarette smokers have a 20 $21 \%$ higher risk of bowel cancer than people who have never smoked; ${ }^{25,48)}$ however the other two, which included some case-control studies, found this effect was not statistically significant ${ }^{(49,50)}$, Three meta-analyses explored the effect of having previously smoked on bowel cancer risk, and all three found ex-smokers' risk was higher than people who have never smoked, by 17 $25 \%{ }^{(48-50)}$.

Smoking is believed to increase risk of $\mathrm{CRC}$ by promoting the formation and growth of adenomas ${ }^{(43)}$.

This study revealed no association between NSAID and CRC; this is also stated by other authors that long-term, regular use of aspirin and other nonsteroidal anti-inflammatory drugs (NSAIDS) is associated with lower risk of CRC ${ }^{(51-52)}$.

Our study found that history of intestinal s polyps was associated with a greater risk of CRC. The results are in agreement with American Cancer Society which stated that, people who have had one or more adenomatous polyps have an increased risk of colorectal cancer. This is especially true if the polyps were large or if there was more than one ${ }^{(3)}$.

The results of this study are in concordance with those of other studies in estimating a much higher CRC risk in cases with inflammatory bowel disease (IBD). Bernstein et al., (53) stated that people who have a chronic IBD have an increased risk of developing CRC which increases with extent and duration of the disease. This includes conditions such as ulcerative colitis and Crohn's disease, in which the colon is inflamed over a long period of time. It is estimated that $18 \%$ of patients with a 30-year history of ulcerative colitis will develop CRC ${ }^{(54)}$.

Regarding the validity of CEA in screening of CRC, our study revealed that at cutoff point $5.5 \mu \mathrm{g} / \mathrm{L}$, the sensitivity and specificity were $80 \%$ and $76 \%$ respectively. This is in agreement with Duffy ${ }^{(55)}$ who stated that serial CEA in screening of CRC with a sensitivity of approximately $80 \%$, a specificity of approximately $70 \%$ but it was of little use in detecting early colorectal cancer. NICE 2004 revealed that the CEA test has a specificity of between $30-80 \%$ and it is not recommended by the National Institute for Health and Clinical Excellence (NICE) for the diagnosis of early colorectal cancer ${ }^{(56)}$.

\section{Conclusion:}

Exposure to personal and environmental risk factors were thought to play an important role in the development of colorectal cancer.

\section{Recommendation:}

Appropriate dietary changes, regular physical activity, and maintenance of healthy weight and avoiding the use of tobacco may reduce risk associated with colorectal cancer.

\section{Limitation of the study:}

Limitations of the study included its hospital-based nature and there was risk of information bias.

\section{References}

1) Lanza $G$, Messerini L, Gafà $R$, Risio M, (2011): Colorectal tumors: The histology report. Digestive and Liver Disease; 43: S344-S355

2) Veruttipong D., Soliman A, Gilbert S, Blachley T, Hablas A, Ramadan M, et al., (2012): 
Age distribution, polyps and rectal cancer in the Egyptian population-based cancer registry; World J Gastroenterol; 18(30): 3997-4003.

3) American Cancer Society (2011): CRC Facts \& Figures 2011-2013. Atlanta: American Cancer Society.

4) Kirkegaard H, Johnsen NF, Christensen J, Frederiksen K, Overvad $K$, Tjonneland A. (2010): Association of adherence to lifestyle recommendations and risk of colorectal cancer: a prospective Danish cohort study. BMJ;341:c5504.

5) Hamilton SR., Rubio CA., Vogelstein B., Sobin LH., Kudo S., Fogt F., et al., (2000): Carcinoma of the colon and rectum. In: Hamilton et al., editors. World Health Organization classification of tumors. Pathology and genetics. Tumors of the digestive system. Lyon, France: IARC Press; pp. 103-19.

6) Jass JR, O'Brien J, Riddell RH, Snover C. (2008): Recommendations for the reporting of surgically resected specimens of colorectal carcinoma: Association of Directors of Anatomic and Surgical Pathology. Am J Clin Pathol;129:13-23.

7) Perkins GL, Slater ED, Sanders GK, Prichard JG. (2003): Serum tumor markers. Am Fam Physician. 15;68(6):1075-82.

8) Ни H, Krasinskas A, Willis J, (2011): Perspectives on current tumor-node-metastasis (TNM) staging of cancers of the colon and rectum. Seminar Oncology;38(4):500-10.

9) Eheman $C$, Henley SJ, Ballard-Barbash R, Jacobs EJ, Schymura MJ, Noone AM, et al., (2012): Annual Report to the Nation on the status of cancer, 1975-2008, featuring cancers associated with excess weight and lack of sufficient physical activity. Cancer 2012, 118(9):2338-2366.

10) Viñes E, Ardanaz A, Arrazola I. (2003): Epidemiología poblacional de cáncer colorrectal: revisión de la causalidad. Population-based epidemiology of colorectal cancer: causality review. Salud Pública Y Administración Sanitaria. An Sis San Navarra.;26(1):enero-abril 7997.

11) Shin A, Joo J, Bak J, Yang HR, Kim J, Park S, et al., (2011): Site-Specific Risk Factors for CRCin a Korean Population. PLoS ONE 6(8): e23196.

12) $\boldsymbol{S E E R} *$ Stat Database: Incidence - SEER 17 Regs Limited-Use + Hurricane Katrina Impacted Louisiana Cases, Nov 2009 Sub (2000-2007) <Katrina/Rita Population Adjustment> Linked To County Attributes Total U.S., 1969-2007 Counties [computer program]: Surveillance, Epidemiology, and End Results (SEER) Program

(www.seer.cancer.gov),

National Cancer Institute, DCCPS, Surveillance Research Program, Cancer Statistics Branch, released April 2010, based on the November 2009 submission. 
13) Levi F, Randimbison L, LaVenchia C.(2005): Following Incidence of CRCadenomatous polyps of the large intestine. Int J Cancer., 5:415-8.

14) Hamilton W, and Lancaschire $\boldsymbol{R}$. (2009): The risk of CRCwith symptoms at different ages and between. The sexes: a casecontrol study. BMC Med. 17; $7: 17$.

15) Murphy G, Devesa SS, Cross AJ, Inskip PD, McGlynn KA, Cook MB. (2011): Sex disparities in CRCincidence by anatomic subsite, race and age. Int J Cancer. 1;128(7):1668-75.

16) Gao R. , Neutel C., Wai E. (2008): Gender differences in CRCincidence, mortality, hospitalizations and surgical procedures in Canada; J Public Health . 30 (2): 194-201.

17) Fernandez E, La Vecchia $C$, Balducci A, Chatenoud L, Franceschi S, Negri E (2001): Oral contraceptives and CRCrisk: a meta-analysis. $\mathrm{Br} \mathrm{J}$ Cancer, 84(5):722-727.

18) Grodstein F, Newcomb PA, Stampfer MJ (1999): Postmenopausal hormone therapy and the risk of colorectal cancer: a review and meta-analysis. Am J Med, 106(5):574-582.

19)Gunter $\quad M J$, Hoover $\quad D R, Y u$ $\mathrm{H}$, Wassertheil-Smoller

S, Rohan TE, Manson JE, et al., (2008): Insulin, insulin-like growth factor-I, endogenous estradiol, and risk of CRCin postmenopausal women. Cancer Res., 68(1):329-337.

20)Clendenen TV, Koenig $K L$, Shore RE, Levitz M, Arslan AA, Zeleniuch- Jacquotte A (2009): Postmenopausal levels of endogenous sex hormones and risk of colorectal cancer.
Cancer Epidemiol Biomarkers Prev., 18(1):275-281.

21) Ritenbaugh C, Stanford JL, Wu L, Shikany JM, Schoen RE, Stefanick ML, et al., (2008): Conjugated equine estrogens and CRCincidence and survival: the Women's Health Initiative randomized clinical trial. Cancer Epidemiol Biomarkers Prev., 17(10):26092618.

22) Lynch HT, and Chapelle A. (2003): Hereditary colorectal cancer. $N$ Engl $J$ Med. ;348(10):919-932.

23)Butterworth AS, Higgins JP, Pharoah P. (2006): Relative and absolute risk of CRCfor individuals with a family history: a meta-analysis. Eur $J$ Cancer.;42(2):216-227.

24) Johns LE, and Houlston RS. (2001): A systematic review and meta-analysis of familial CRCrisk. Am

Gastroenterol.;96(10):29923003.

25) Huxley $\quad R R, \quad$ AnsaryMoghaddam A, Clifton $P$, Czernichow S, Parr CL, Woodward M. (2009): The impact of dietary and lifestyle risk factors on risk of colorectal cancer: a quantitative overview of the epidemiological evidence. Int $J$ Cancer.;125(1):171-180.

26) Dai Z, Xu YC, Niu L (2007): Obesity and CRCrisk: a metaanalysis of cohort studies. World J Gastroenterol 2007, 13(31):4199-4206. 4. Larsson SC, Wolk A: Obesity and colon and rectal cancer risk: a metaanalysis of prospective studies. Am J Clin Nutr., 86(3):556-565.

27) Renehan AG, Tyson M, Egger $M$, Heller RF, Zwahlen M 
(2008): Body-mass index and incidence of cancer: a systematic review and metaanalysis of prospective observational studies. Lancet, 371(9612):569-578.

28) Pischon T, Lahmann $\mathrm{PH}$, Boeing $\quad \mathrm{H}$, Friedenreich $C$, Norat T, Tjønneland A, et al., (2006): Body size and risk of colon and rectal cancer in the European Prospective Investigation Into Cancer and Nutrition (EPIC). J Natl Cancer Inst., 98(13):920-931.

29) Jee SH, Yun JE, Park EJ, Cho ER, Park IS, Sull JW, et al., (2008): Body mass index and cancer risk in Korean men and women. Int $\mathbf{J}$ Cancer 123: 1892-1896.

30) Song YM, Sung J, Ha M (2008): Obesity and risk of cancer in postmenopausal Korean women. J Clin Oncol 26: 3395-3402.

31) Na SY, Myung SJ. (2012): Obesity and colorectal cancer, Korean J Gastroenterol.; 59(1):16-26.

32) Boyle T., (2012): Physical Activity and Colon Cancer Timing, Intensity, and Sedentary Behavior, American journal of lifestyle medicine. 6(3); 204-215

33) Wolin KY, Yan Y, Colditz GA, Lee IM. (2009): Physical activity and colon cancer prevention: a meta-analysis. $\mathrm{Br}$ J Cancer.;100(4):611-616

34) Halle M, and Schoenberg MH. (2009): Physical activity in the prevention and treatment of colorectal carcinoma. Dtsch Arztebl Int.;106(44):722-727.

35) Qasim A, and O'Morain $C$. (2010): Primary prevention of colorectal cancer: are we closer to reality? Eur J Gastroenterol Hepatol.;22(1):9-17

36) Chan AT, and Giovannucci EL. (2010): Primary prevention of colorectal cancer. Gastroenterology.; 138(6):2029-2043.

37) Samad AK, Taylor $R S$, Marshall T, Chapman MA. (2005): A meta-analysis of the association of physical activity with reduced risk of colorectal cancer.

Colorectal Dis.;7(3):204-213.

38) Chao A, Connell CJ, Jacobs EJ, McCullough ML, Patel $A V$, Calle EE, et al., (2004): Amount, type, and timing of recreational physical activity in relation to colon and rectal cancer in older adults: the Cancer Prevention Study II Nutrition Cohort. Cancer Epidemiol Biomarkers Prev.; 13(12):2187-2195.

39) Cross AJ, Ferrucci LM, Risch A, Graubard BI, Ward MH, Park Y, et al., (2010): A large prospective study of meat consumption and CRCrisk: an investigation of potential mechanisms underlying this association. Cancer Res.;70(6):2406-2414.

40) Miller PE, Lesko SM, Muscat JE, Lazarus P, Hartman TJ. (2010): Dietary patterns and colorectal adenoma and cancer risk: a review of the epidemiological evidence. Nutr Cancer.;62(4):413-424.

41)Food, Nutrition, Physical Activity, and the Prevention of Cancer (2007): a Global Perspective. Washington DC: World Cancer Research Fund / American Institute for Cancer Research 2007.

42) Ferguson LR. (2010): Recent advances in understanding of 
interactions between genes and diet in the etiology of colorectal cancer. World $J$ Gastrointest Oncol:;2(3):125-129.

43) Sung MK, and Bae YJ.(2010): Linking obesity to colorectal cancer: application of nutrigenomics. Biotechnol J. 2010;5(9):930-941.

44) Seow A, Yuan JM, Koh WP, Lee HP, Yu MC (2006): Diabetes mellitus and risk of CRCin the Singapore Chinese Health Study. J Natl Cancer Inst 2006, 98(2):135-138.

45) Sandhu MS, Dunger DB, Giovannucci EL (2002): Insulin, insulin-like growth factor-I (IGF-I), IGF binding proteins, their biologic interactions, and colorectal cancer. J Natl Cancer Inst., 94(13):972-980.

46) Cowey S, and Hardy $R W$ (2006): The metabolic syndrome: A high-risk state for cancer? Am J Pathol 169: 1505-1522.

47) Larsson SC, Orsini N, Wolk A (2005): Diabetes mellitus and risk of colorectal cancer: a meta-analysis. J Natl Cancer Inst 97: 1679-1687.

48) Tsoi KK, Pau CY, Wu WK, Chan FK, Griffiths S, Sung JJ. (2009): Cigarette smoking and the risk of colorectal cancer: a metaanalysis of prospective cohort studies. Clin Gastroenterol Hepatol.;7(6):682-88 e1-5.

49) Botteri $\quad E$, Iodice $S$, Bagnardi $V$, Raimondi $\quad S$, Lowenfels AB, Maisonneuve P. (2008): Smoking and colorectal cancer: a meta-analysis. JAMA ;300(23):2765-78.

50) Liang PS, Chen TY, Giovannucci E. (2009):

Cigarette smoking and CRCincidence and mortality: systematic review and metaanalysis. Int J Cancer;124(10):2406-15.

51) Flossmann $E$ and Rothwell PM. (2007): Effect of aspirin on long-term risk of colorectal cancer: consistent evidence from randomised and observational studies. Lancet.;369(9573):1603-1613.

52) Rothwell PM, Wilson $M$, Elwin CE, Norrving B, Algra $A$, Warlow CP, et al., (2010): Long-term effect of aspirin on CRCincidence and mortality: 20-year follow-up of five randomized trials. 20;376(9754):1741-50.

53) Bernstein CN, Blanchard JF, Kliewer E, Wajda A. (2001): Cancer risk in patients with inflammatory bowel disease: a population-based study. Cancer. 15;91(4):854-862.

54) Eaden JA, Abrams KR, Mayberry JF. (2001): the risk of CRC in ulcerative colitis: a meta-analysis. Gut. 48(4):526535.

55) Duffy $\quad$ MJ. (2001): Carcinoembryonic antigen as a marker for colorectal cancer: is it clinically useful?; Clin Chem. ;47(4):624-30.

56) NICE (2004): Service guidance for the NHS in England and Wales Improving Outcomes for CRC(update). 
Table (1): Clinical \& demographic data Colorectal cancer (CRC) patients studied:

\begin{tabular}{|l|l|l|l|}
\hline Variables & Number of cases & Percentage (\%) \\
\hline \multirow{3}{*}{ Age (years) } & $45-$ & 3 & 12 \\
\cline { 2 - 4 } & $55+$ & 22 & 88 \\
\hline \multirow{3}{*}{ Sex } & Female & 9 & 36 \\
\cline { 2 - 4 } & Male & 16 & 64 \\
\hline \multirow{2}{*}{ Obiver metastasis } & Present & 7 & 28 \\
\cline { 2 - 4 } & Absent & 18 & 72 \\
\hline \multirow{2}{*}{ Endruction } & Present & 10 & 40 \\
\cline { 2 - 4 } & Absent & 15 & 60 \\
\hline \multirow{2}{*}{ CEA (mcgic masses } & Present & 20 & 80 \\
\cline { 2 - 4 } & Absent & 5 & 20 \\
\hline Total & $<5$ & 5 & 20 \\
\cline { 2 - 4 } & $\geq 5$ & 20 & 100 \\
\hline
\end{tabular}

Table (2): Histopathological findings of Colorectal cancer (CRC) cases studied:

\begin{tabular}{|c|c|c|c|}
\hline \multicolumn{2}{|l|}{ Variables } & \multirow{2}{*}{$\begin{array}{l}\begin{array}{c}\text { Number of cases } \\
(\mathbf{n}=\mathbf{2 5})\end{array} \\
20\end{array}$} & \multirow{2}{*}{$\begin{array}{l}\text { Percentage (\%) } \\
80\end{array}$} \\
\hline Gross features & Polypoid masses & & \\
\hline & Ulcers & 5 & 20 \\
\hline \multirow[t]{2}{*}{ Grade } & Well / moderate & 18 & 72 \\
\hline & Poor & 7 & 28 \\
\hline \multirow{2}{*}{$\begin{array}{l}\text { Associated } \\
\text { inflammation }\end{array}$} & Present & 4 & 16 \\
\hline & absent & 21 & 84 \\
\hline \multirow{2}{*}{ Specimen } & Biopsy & 20 & 80 \\
\hline & Resection & 5 & 20 \\
\hline \multicolumn{4}{|c|}{ From resection cases $(n=5)$ : } \\
\hline \multirow[t]{3}{*}{ Stage } & I & 1 & 20 \\
\hline & II & 1 & 20 \\
\hline & III & 3 & 60 \\
\hline \multirow[t]{2}{*}{ Lymph node status } & Present & 3 & 60 \\
\hline & Absent & 2 & 40 \\
\hline
\end{tabular}


Table (3): Comparison between cases and control as regards age, sex and Family history:

\begin{tabular}{|c|c|c|c|c|c|c|}
\hline & & $\begin{array}{l}\text { Cases } \\
(\mathrm{n}=25)\end{array}$ & $\begin{array}{l}\text { Control } \\
(n=100)\end{array}$ & $\begin{array}{l}\text { Odd } \\
\text { ratio }\end{array}$ & $95 \% \mathrm{CI}$ & P-value \\
\hline Age (years) & $>55$ & $21(84 \%)$ & $67(67 \%)$ & 26 & 0001 & 000 \\
\hline & $45-$ & $4(16 \%)$ & $33(33 \%)$ & & & \\
\hline Soy & Male & $16(64 \%)$ & $63(63 \%)$ & 104 & 04276 & ר 0 ר \\
\hline Sex & Female & $9(36 \%)$ & $37(37 \%)$ & 1.04 & $0.42-2.0$ & 0.92 \\
\hline Family history & $+\mathrm{ve}$ & $1(4 \%)$ & $1(1 \%)$ & $11+>$ & & \\
\hline of CRC & - ve & $24(96 \%)$ & $99(99 \%)$ & 4.1 & $0.5-00.5$ & 0.50 \\
\hline
\end{tabular}

Table (4): Comparison between cases and control as regards risk factors:

\begin{tabular}{|c|c|c|c|c|c|c|}
\hline \multicolumn{2}{|c|}{ Variables } & Cases & Control & Odd & $95 \% \mathrm{CI}$ & P-value \\
\hline \multirow{2}{*}{ BMI } & $\geq 30$ & $16(64 \%)$ & $33(33 \%)$ & \multirow{2}{*}{3.6} & \multirow{2}{*}{$1.4-9.02$} & \multirow{2}{*}{$<0.001$} \\
\hline & $<30$ & $9(36 \%)$ & $67(67 \%)$ & & & \\
\hline \multirow{3}{*}{$\begin{array}{l}\text { Physical } \\
\text { activity }\end{array}$} & Low (light) & $19(76 \%)$ & $65(65 \%)$ & 1.9 & $0.4-9.2$ & \multirow{3}{*}{0.57} \\
\hline & Moderate & $4(16 \%)$ & $22(22 \%)$ & 1.2 & $0.2-7.4$ & \\
\hline & High & $2(8 \%)$ & $13(13 \%)$ & 1.0 & Referent & \\
\hline \multirow{2}{*}{$\begin{array}{l}\text { Dietary } \\
\text { Pattern }\end{array}$} & $\begin{array}{c}\text { Mostly meat } \\
\text { eater }\end{array}$ & $22(88 \%)$ & $65(65 \%)$ & \multirow{2}{*}{3.9} & \multirow{2}{*}{$1.1-14.1$} & \multirow{2}{*}{0.04} \\
\hline & $\begin{array}{c}\text { Mostly } \\
\text { Vegetarian }\end{array}$ & $3(12 \%)$ & $35(35 \%)$ & & & \\
\hline \multirow{2}{*}{$\begin{array}{c}\text { History of } \\
\text { DM }\end{array}$} & Yes & $19(76 \%)$ & $51(51 \%)$ & \multirow{2}{*}{3.04} & \multirow{2}{*}{$1.1-8.3$} & \multirow{2}{*}{0.02} \\
\hline & No & $6(24 \%)$ & $49(49 \%)$ & & & \\
\hline \multirow{3}{*}{ Smoking } & $\begin{array}{l}\text { Current } \\
\text { Smoker }\end{array}$ & $14(56 \%)$ & $35(35 \%)$ & 4.7 & $1.4-15.5$ & \multirow{3}{*}{0.02} \\
\hline & Non- smoker & $4(16 \%)$ & $47(47 \%)$ & 1.00 & Referent & \\
\hline & Ex-smoker & $7(28 \%)$ & $18(18 \%)$ & 4.6 & $1.2-17.5$ & \\
\hline \multirow{2}{*}{$\begin{array}{c}\text { NSAID for } \\
\text { chronic } \\
\text { diseases }\end{array}$} & Yes & $11(44 \%)$ & $51(51 \%)$ & \multirow{2}{*}{0.8} & \multirow{2}{*}{$0.3-1.8$} & \multirow{2}{*}{0.5} \\
\hline & No & $14(66 \%)$ & $49(49 \%)$ & & & \\
\hline \multirow{2}{*}{$\begin{array}{l}\text { Intestinal } \\
\text { polyp }\end{array}$} & Yes & $21(84 \%)$ & $47(47 \%)$ & \multirow{2}{*}{5.9} & \multirow{2}{*}{$1.74-22.0$} & \multirow{2}{*}{$<0.001$} \\
\hline & No & $4(16 \%)$ & $53(53 \%)$ & & & \\
\hline \multirow{2}{*}{$\begin{array}{l}\text { History of } \\
\text { IBD }\end{array}$} & Yes & $18(72 \%)$ & $56(56 \%)$ & \multirow{2}{*}{2.02} & \multirow{2}{*}{$0.7-5.9$} & \multirow{2}{*}{0.15} \\
\hline & No & $7(28 \%)$ & $44(44 \%)$ & & & \\
\hline
\end{tabular}


Table (5): sensitivity and specificity of Carcinoembryonic Antigen (CEA) at different cut-off points:

\begin{tabular}{|c|c|c|}
\hline $\begin{array}{c}\text { Positive if Greater Than or } \\
\text { Equal To }\end{array}$ & Sensitivity (\%) & $1-$ Specificity (\%) \\
\hline 2.25 & 92.0 & 80.0 \\
\hline 2.7 & 88.0 & 72.0 \\
\hline 4.5 & 80.0 & 28.0 \\
\hline 5.5 & 80.0 & 24.0 \\
\hline 9.5 & 6.04 & 12.0 \\
\hline 11 & 6.0 & 12.0 \\
\hline
\end{tabular}

ROC curve for CEA

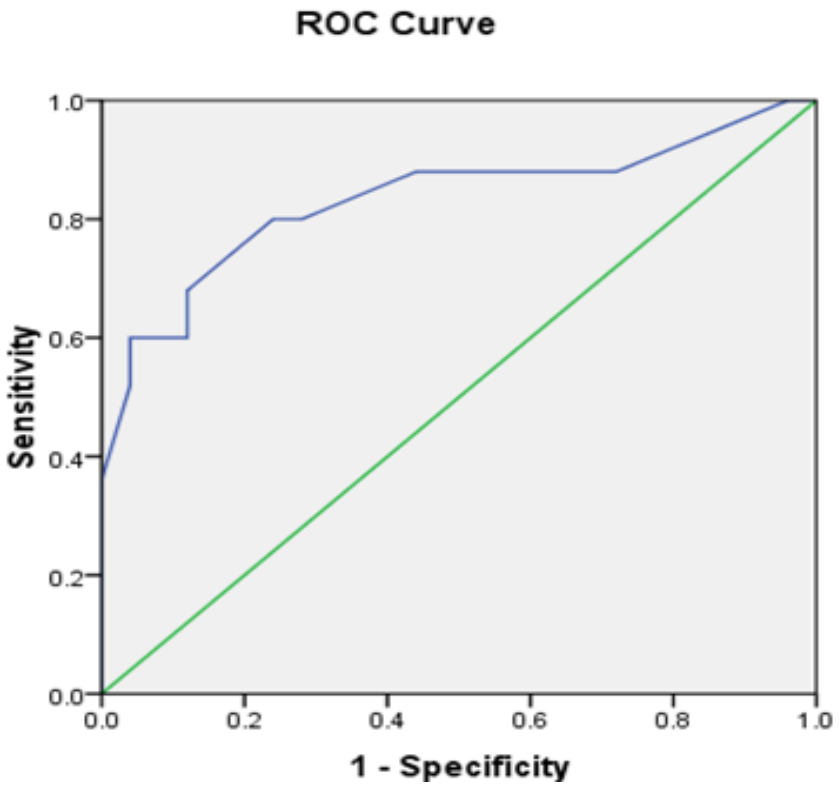

Area under the curve $\quad P$-value

$$
0.8<0.001
$$




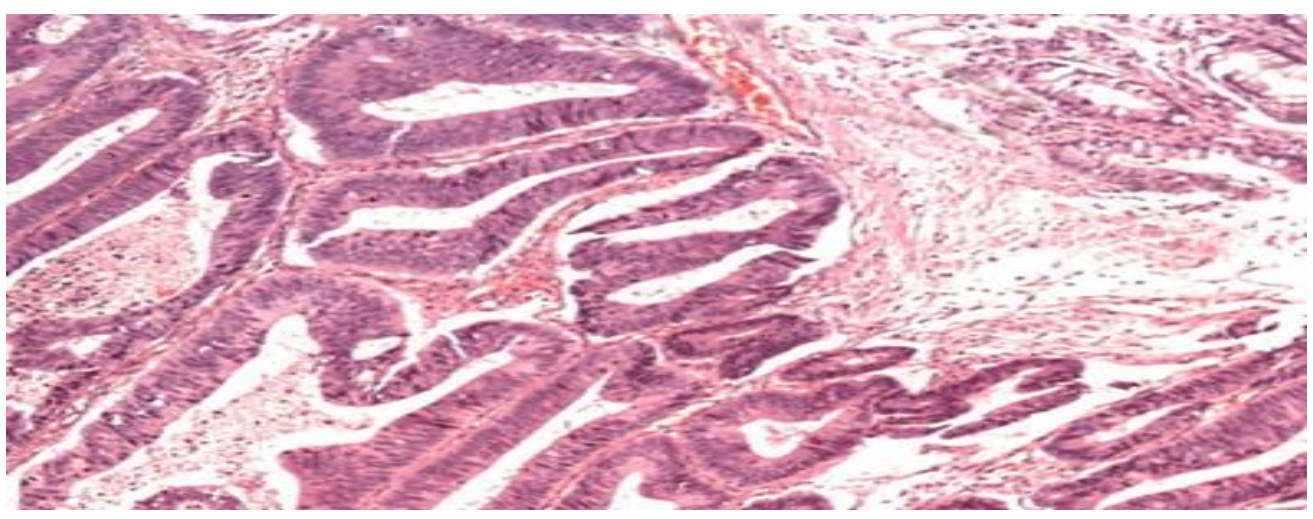

Fig 1: A case of well differentiated CRC from sigmoid colon showed well-formed malignant glands with intra-glandular necrosis (H\&E X100)

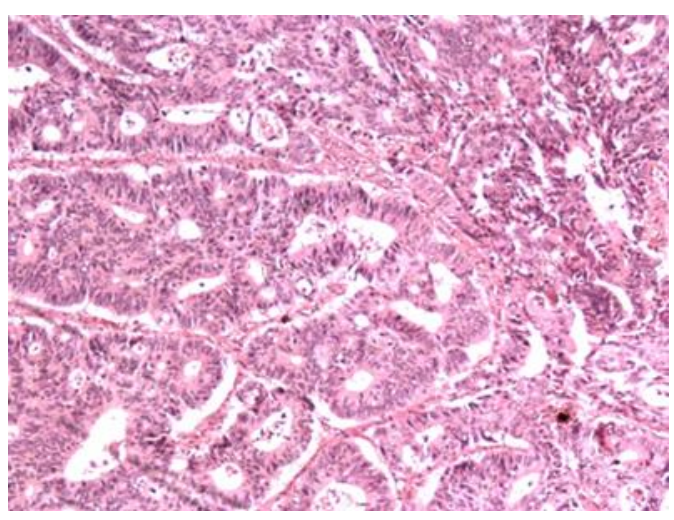

Fig 2 (a): A case of moderately differentiated CRC from rectum (H\&E $\mathrm{X} 100)$

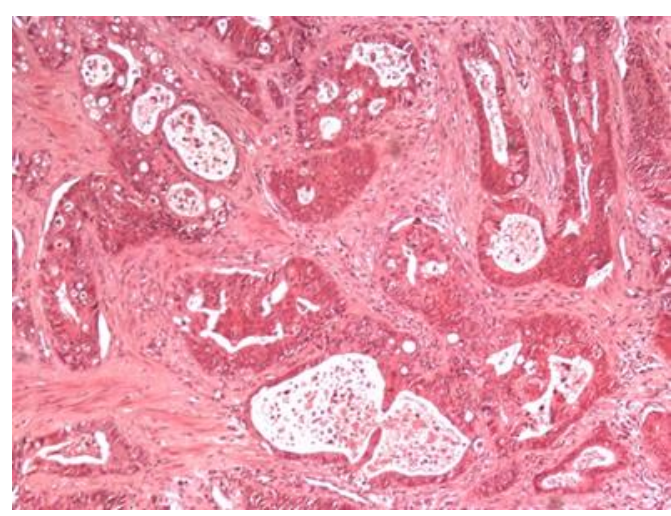

Fig 2 (b): A case of moderately differentiated CRC from sigmoid colon with transmural invasion(H\&E X100)

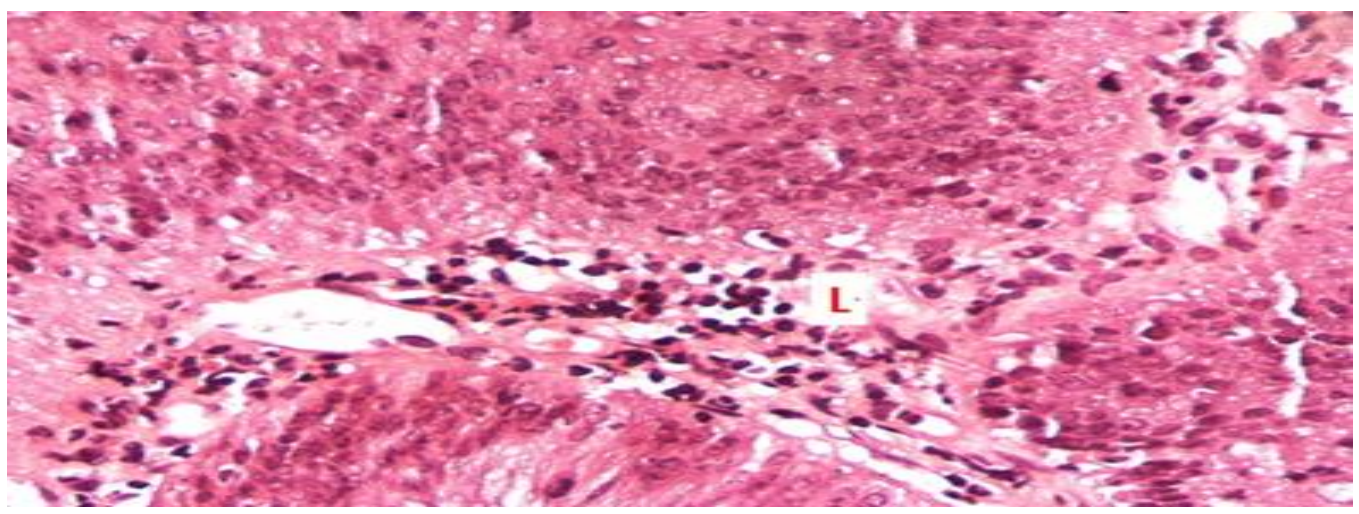

Fig 3: A case of well differentiated CRC revealed malignant glands with stromal lymphocytes (L)(H\&E X100) 